\title{
Exploring Entrepreneurial Intentions in Marien Ngouabi University Students
}

\author{
Edwige Kamitewoko \\ Marien Ngouabi University, Brazzaville, Republic of Congo \\ Email: aijiaae@yahoo.fr
}

How to cite this paper: Kamitewoko, E. (2021). Exploring Entrepreneurial Intentions in Marien Ngouabi University Students. Open Journal of Social Sciences, 9, 75-93.

https://doi.org/10.4236/jss.2021.911007

Received: September 10, 2021

Accepted: November 9, 2021

Published: November 12, 2021

Copyright (c) 2021 by author(s) and Scientific Research Publishing Inc. This work is licensed under the Creative Commons Attribution International License (CC BY 4.0).

http://creativecommons.org/licenses/by/4.0/

(c) (i) Open Access

\begin{abstract}
The aim of this study was to examine the factors that would likely influence the entrepreneurial intention of the students in Marien Ngouabi university which is one of the public Higher Education in Congo. The entrepreneurial intentions of students were determined using demographic, individual, Contextual and Personality variables. The primary data were collected through a questionnaire survey method. A total of 3000 students have been included from different programs such as economics, sport, commerce, sciences, computer and IT, medical sciences, agriculture, engineering, art and law. Using logistic regression, findings suggest that gender, tutor education, field of study, parents owning a business, having a job while at university, parent's monthly income, desire for independence, living with parents together, school calendar were the key factors that influence students' entrepreneurial intention. The results of this study will help in understanding the phenomenon of entrepreneurial intention among university students and help policy makers in promoting and developing future entrepreneurs in university.
\end{abstract}

\section{Keywords}

Entrepreneurial Intention, Logistic Regression, University Students, Marien Ngouabi University

\section{Introduction}

Entrepreneurship has attracted attention among scholars because of its importance in economic growth, job creation and productivity (Acheampong \& Tweneboah-Koduah, 2018; Elliott, Mavriplis, \& Anis, 2020). The enthusiasm for entrepreneurship is obviously felt all over the world, in developed countries, but increasingly in developing countries as well, such as the case in Congo Brazzaville, a country willing to put into place development policies driven by other 
industrial sectors than hydrocarbons. The increasing number of students graduating in all majors and the limited employment opportunities supplied by the government pushed Marien Ngouabi University to promote the interest of graduates to become future entrepreneurs. Since entrepreneurship is associated with self-employed individuals, it is perceived to be an effective approach to address the challenge of employability, especially among young people. As the graduates cannot always depend on the public and private sectors in providing job opportunities, entrepreneurship tends to be the alternative solution for their unemployment (Iro-Idoro et al., 2017).

Indeed, in Congo, it used to be that if you graduated from university, with good grades, you were guaranteed a job in your chosen field. But as more and more people go to university, this is no longer the case. Although students graduated from the top one university, but job opportunities are still not guaranteed for them.

Part of the government effort to instill entrepreneurial spirit among university students is to make entrepreneurship subject compulsory to all students regardless of their field of study.

Research by Pihie and Akmaliah (2009) posited that there is a need for universities to enhance their teaching strategies in order to improve entrepreneurial self-efficacy and desire among students to opt for entrepreneurship as a career choice. According to Räty, Komulainen, Hytti, Kasanen, Siivonen, \& Kozlinska (2019), entrepreneurship has been recognized as one of the tools that drive the economy of a country. Alla \& Rajâa (2019) pointed out that entrepreneurial activities are not only the incubator of technological innovation, but they also provide employment opportunities and increase competitiveness. Entrepreneurship has been given serious devotion due to its importance on economic growth, job creation, sources of innovation, and productivity (Mustafa \& Abbas, 2021).

Given the role that entrepreneurship play in the economic development of a country, researchers acknowledge that students or young people are the key population for entrepreneurial activities. They are a very important source of nascent entrepreneurship in developing nations like Congo Brazzaville. A majority of these students will immediately contribute more to the economic growth after they graduate, not as salary workers but as entrepreneurs. They are considered to represent the power, the creativity of nations with many dreams and ambitions. Therefore, it's important to figure out what drives students to pursue entrepreneurship. Thus, there is a call to conduct a research to understand the determinants of students to involve in entrepreneurship. The paper is set out as follows: Section 2 reviews the literature. In the following section, we describe the methodology, after having presented our methodology, Section 4 provides results. Finally, in the last section, we conclude and make suggestions for future research avenues and more appropriate public policies for youth entrepreneurship in Congo will be made. 


\subsection{Research Questions}

What are the determinants of entrepreneurial intentions of Congolese students? Which factors can motivate and hinder the entrepreneurial intentions among university students in Congo Brazzaville?

\subsection{Objective of the Study}

This study aims to identify the motivational factors which can support university student in Congo Brazzaville to become entrepreneurs.

\subsection{Significance of the Study}

This study would have the potential to contribute at least the following aspects. First and foremost, this study will contribute a lot to the university in order to thoroughly understand its students towards self-employment intention and take a remedy/action in creating entrepreneurial environment which stimulates students to become self-employed/entrepreneurs since universities are expected to incubate entrepreneurs rather than institutions to produce those who are waiting jobs/employment opportunities from government, non-government organizations.

Second, the subjects of this study will be benefited from the study by getting some insights regarding the importance of self-employment/entrepreneurship. Many studies on entrepreneurship intention have been done in so many places such as South Africa, America, Asia, Europe, and America. However, there have never been many studies on entrepreneurship intention among the University students in central Africa, and particularly in Congo Brazzaville, therefore this study has come about to fill this particular gap.

\subsection{Originality/Value}

Over the past decades, universities have been receiving an increasing demand to go beyond their role of producing science and technology to explore its knowledge potential to produce novel commercial applications. Therefore, while there is a growing interest in ways to foster scientific, academic entrepreneurship, universities also serve as a positive environment for student entrepreneurship training, knowledge sharing, testing ideas, and learning. So far, the importance of student entrepreneurship has received more attention than it likely deserves. This study fulfils the need to identify the factors which play a significant role in influencing the students' entrepreneurial mindset. This is a latest study with the selected factors in the context of the Congolese university students.

\section{Literature Review and Conceptual Framework}

\subsection{Introduction}

For a better understanding of entrepreneurial behavior, this chapter provides the definition of Core Concepts and some highlights of previous research on entrepreneurial intentions. 


\subsection{Definition of Core Concepts}

\subsubsection{Entrepreneurship}

The term "entrepreneurship" was first mentioned by French economist Cantillon, 1755 (Hisrich et al., 2005). It is derived from a French word Entreprendre which means to start or to execute (Parker, 2009). Since then, many scholars have come up with different definitions of the terminology in different perspectives. Morris et al. (2005) found more than 70 different definitions of "entrepreneurship". Almost definitions are related to starting a new business, or self-employed. Other definitions emphasize a wide range of activities, including organization creation, resources combination in new ways, exploration of opportunities, and risk-taking acceptance. Schumpeter (1934) argued that "entrepreneurship" is the spirit of creativity and innovation. Also, according to Nowiński, Haddoud, Lančarič, Egerová, \& Czeglédi (2019), "entrepreneurship" is a creative activity that involves taking advantage of available resources to create wealth in a new way. From those perceptions of entrepreneurship mentioned above, we propose entrepreneurship as any deliberate action by groups of people, communities or individuals in starting or engaging in business activities either formally or informally to make a profit. Entrepreneurial stimulation refers to those deliberate attempts to steer or increase entrepreneurship activities.

\subsubsection{Entrepreneurial Intention}

Entrepreneurial intention is described as the individuals intention to build up a new business undertaking or to be self-employed (Iakovleva and Kolvereid, 2009); Phong, Thao, \& Nguyen (2020) described entrepreneurial intentions as the exploration and assessment of information which is beneficial to achieve the objective of business creation. The focus of entrepreneurship is to have entrepreneurial intentions before starting the actual business because it determines the starting point of a new business creation (Alkhatib, Al-Aiad, Mustafa, \& Alzubi, 2020).

Nathani and Dwivedi (2019) and Ismail, Ibrahim, Yaacob, Ibrahim, Zakaria, Razak, Yusoff, Guan, and Kamaruddin (2018) give explanation for entrepreneurial intention as a mental orientation for individuals include hope, wish, and desire that affect the choice for entrepreneurship.

\subsubsection{Theories of Entrepreneurial Intention}

Previous studies have contributed to the entrepreneurship literature by using intentional models in trying to explain the entrepreneurship phenomenon.

One of these models is Shapero and Sokol's (1982) model of the "Entrepreneurial Event" (SEE). This one is implicitly an intention model, which is specific to the domain of entrepreneurship (Krueger Jr. et al., 2000). The entrepreneurial event was defined as the unit of interest primarily due to the problems associated with defining what an entrepreneur is in distinction to other individuals. Shapero and Sokol (1982) suggested that the entrepreneurial event comprises five characteristics: 1) initiative-taking 2) consolidation of resources 3) management 
of the organisation 4) relative autonomy 5) risk taking. Thus, in this approach, the entrepreneurial event could concern the formation of a new business. However, the inheritance of a business may also be regarded as an entrepreneurial event. Another well-recognized model is based on Ajzen's theory of planned behavior (Ajzen, 1991) wherein the individual's behavior is best predicted by one's intentions; intentions are, in turn, predicted by attitudes about the behavior, the subjective norms (a person's perception of important others' beliefs that he or she should or should not perform the behavior) encasing the execution of the behavior, and the individual's perception of their control over the behavior. Thus, according to Ajzen, intentions are explained by: a) subject's attitudes toward the behavior; b) subjective norms and c) the subject's perception of behavioral control.

Another model of intentions was developed by Bird (1988). His model of entrepreneurial intentionality is grounded in theory in cognitive psychology that attempts to explain or predict human behavior. Intentions have been conceptualized as being a function of beliefs that provide a link between beliefs and subsequent behavior (Fishbein \& Ajzen, 1975). That is, people form attitudes toward performing a given behavior based on beliefs that performing the behavior will result in certain consequences, as well as normative beliefs about the behavior. Behavioral intention results from attitudes and becomes the immediate determinant of behavior. Fishbein \& Ajzen (1975) illustrate this relationship as follows; Beliefs $\rightarrow$ Attitudes $\rightarrow$ Intentions $\rightarrow$ Behavior. It is further suggested that there should be a strong relationship between the intention to perform a certain behavior and the actual performance of that behavior. Accordingly, it is proposed that "if one wants to know whether or not an individual will perform a given behavior, the simplest and probably most efficient thing one can do is to ask the individual whether he [or she] intends to perform that behavior". Factors that influence the relationship between intention and behavior include the degree to which the intention and behavior are measured at the same level of specificity, the stability of the intention over time, and volitional control or the degree to which the person is able to carry out the intention.

Further development of the Bird's model was made by Boyd and Vozikis (1994) to include the concept of self-efficacy taken from the social learning theory. Another model was proposed by Davidsson (1995).

\subsubsection{Factors Influencing Entrepreneurial Intention}

Factors affecting entrepreneurial intention may be internal that is personality traits or external that is the general environmental factors such as religion teaching, culture, political, and economic factors.

\subsubsection{Internal Factors}

From the substantial number of previous research on entrepreneurial intention, it has been identified that three factors dominate entrepreneurial intention. One 
is his demographic profile that includes age, sex (gender), previous experience (whether they had a job while at university), and influence of role model (Mustafa, Alzubi, \& Alshare, 2020). Second one is personality traits that include self-efficacy, confidence, autonomy (whether they received pocket money or scholarship while at university, desire for independence), locus of control, risk-taking tendency, and professional attraction. Third factor is contextual that includes education and environment (Wärneryd, 1988; Sun, Chen, Wu, \& Yang, 2020).

According to trait theory of entrepreneurship, entrepreneurial intentions are dictated by some particular traits. Those are: High need for achievement; which means a need to always achieve new bold goals, risk-taking propensity; which defined as a willingness to take financial risks, tolerance for ambiguity; which refers no fear of the unknown, innovation; which is an ability to create new or modify existing business concepts, intuition; which is synonymous of making decisions based on "gut feelings", internal locus of control which is synonymous to a belief that the future is determined by their own actions and also proactiveness; which is making plans for events before they occur (Boyd and Vozikis, 1994; Nabil, 2021).

\subsubsection{External Factors}

According to environmental approach theory-Choice, entrepreneurship is related to external factors beyond the individual's control, seen as a cultural phenomenon, education (Entrepreneurial knowledge, field of study) and experience, family background (whether parents own business; parent's monthly income, tutor's education, self-employed parents, whether parents live together with him), school calendar. Adze et al. (2018) worked on some factors to identify the determinants of entrepreneurial intentions among students in the democratic republic of Congo. They investigated the effect of innovation, education, family background, and gender difference on creating intentions. They found innovativeness and family business experience are related with entrepreneurial intention. Contingency theory of entrepreneurship suggests that people do not become entrepreneur willingly rather situations or contingencies force them to become so. In such situations, they have some motivations for becoming entrepreneurs in certain situations (Dahlstedt \& Fejes, 2019). Based on some previous research, it is important to test the influence of internal and external factors in stimulating student intention at university in entrepreneurship. The framework of this research can be seen in Figure 1.

Based on the description above, the hypothesis in this study are:

Hypothesis 1: Demographic factors and individual background, such as age, gender, education, and work experience have an influence on entrepreneurial intentions.

Hypothesis 2: students' environment is a determinant factor of entrepreneurial intention.

Hypothesis 3: The perceived students' capability (personal factors) positively 


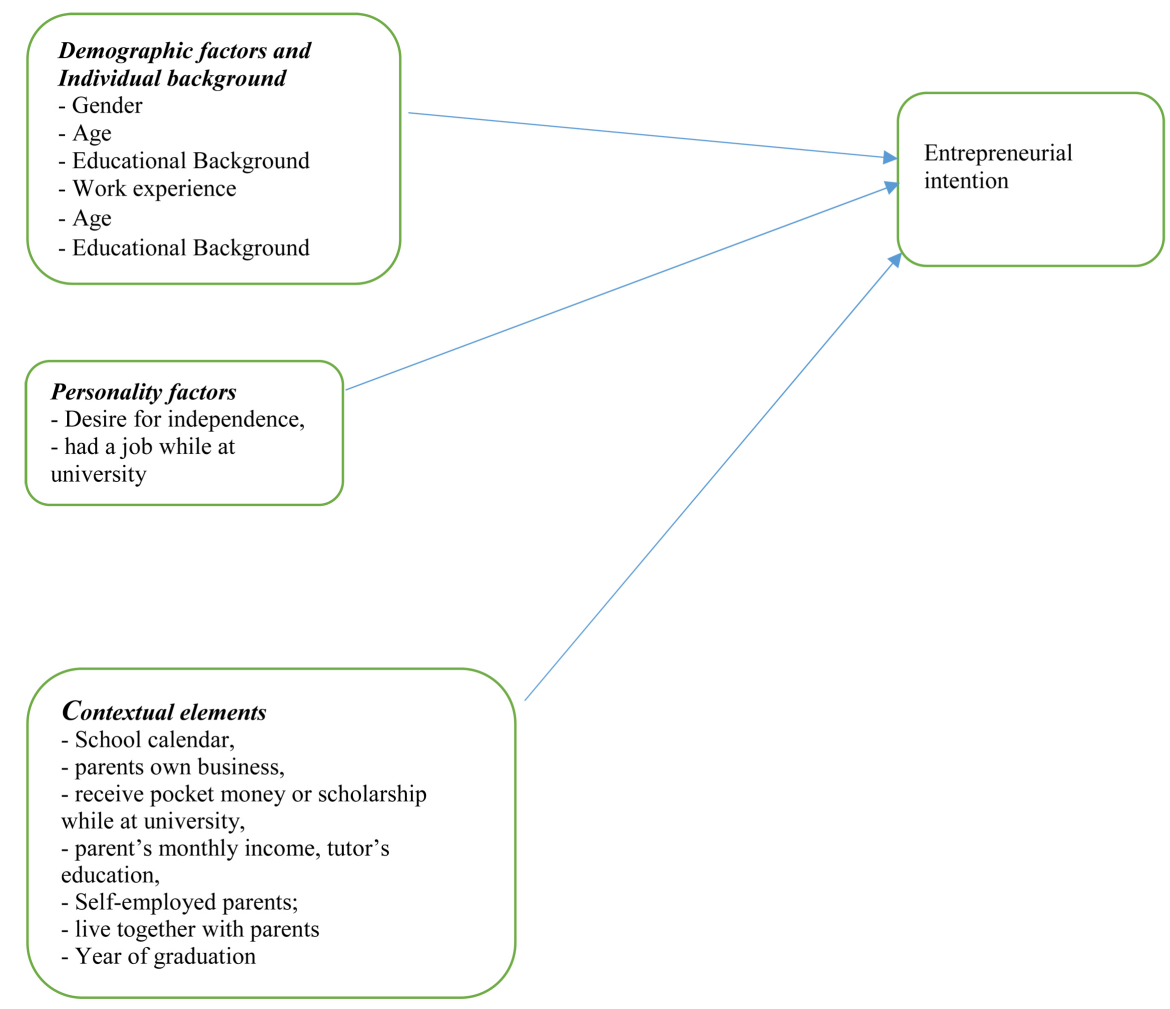

Figure 1. Research model.

influences their entrepreneurial intention.

\section{Methodology}

\subsection{Data Collection}

This study uses a quantitative research method where data is collected from a survey conducted at Marien Ngouabi University in Congo-Brazzaville through the distribution of questionnaires. The data was gathered at university-enterprise partnerships department. The survey was structured and planned at a time when student's graduates were gathered at university-enterprise partnerships department in May 2019, for seminar about self-marketing conducted by this department.

Sample selection: Survey data were collected from university student's graduates where efforts were made not only to include students who have taken entrepreneurial courses and those who have not but also to ensure female students were represented. A total of 3000 students were selected, but, only 2548 students responded to the survey, they were graduates from different major areas, aged between 20 and 35 years old. The questionnaire was pilot tested in center of research and prospective studies, and the Cronbach alpha tests were carried out to determine the reliability of the questions.

\subsection{Dependent Variable}

The dependent variable is entrepreneurial intention. The entrepreneurial inten- 
tion is further segregated into disagree, neutral and agree. Of the 2548 respondents $18.58 \%$ did not want to be entrepreneurs, $41.72 \%$ were not sure about it, $39.7 \%$ had strong entrepreneurial intentions.

\subsection{Independent Variables}

The choices of explanatory variables are based on the objective of study and variables that affect the student behavior on their future professional.

The following variables were considered as the explanatory/independent variables: age, gender, field of study, whether parents own business, whether they received pocket money or scholarship while at university, whether they had a job while at university, parent's monthly income, tutor's education, self-employed parents; school calendar, desire for independence, year of graduation, whether parents live together with him. These variables are represented in Table 1.

Besides, the summary statistics of these variables are represented in Table 2.

Table 1. Dependent and independent variables.

\begin{tabular}{|c|c|}
\hline \multicolumn{2}{|l|}{ Dependent variable } \\
\hline Entrepreneurial intention & $1=$ disagree, $2=$ neutral and $3=$ agree \\
\hline \multicolumn{2}{|l|}{ Independent variables } \\
\hline Age & taking dummy variable, 1 if $20-35$ years and, 0 otherwise $(35+$ years $=$ reference $)$ \\
\hline Gender & taking dummy variable, 1 if female and, 0 otherwise (Male = reference category) \\
\hline Field of study & $\begin{array}{l}\text { taking dummy variable, } 1 \text { if business management course and, } 0 \text { otherwise } \\
\text { (Other courses = reference category) }\end{array}$ \\
\hline Whether parents own a business & $\begin{array}{l}\text { taking dummy variables, } 1 \text { if parents own a business and, } 0 \text { otherwise } \\
\text { (parents don't own = reference category) }\end{array}$ \\
\hline Pocket Money received in university & $\begin{array}{l}\text { taking dummy variables, } 1 \text { if received and } 0 \text { otherwise } \\
\text { (Not received = reference category) }\end{array}$ \\
\hline Had a job while in university & $\begin{array}{l}\text { taking dummy variables, } 1 \text { if had a job and } 0 \text { otherwise } \\
\text { (No job = reference category) }\end{array}$ \\
\hline tutor's education & $\begin{array}{l}\text { taking dummy variables, } 1 \text { if educated and, } 0 \text { otherwise } \\
\text { (Not educated = reference category) }\end{array}$ \\
\hline Parent's monthly income & $\begin{array}{l}\text { income } 1=1 \text { if the parent's monthly income is } 100,000-199,000 \text { income } 2=1 \\
\text { if the parent's monthly income is more } 199,000\end{array}$ \\
\hline Self-employed parents & $\begin{array}{l}\text { taking Dummy variable with value } 1 \text { if the mother, father or both are } \\
\text { self-employed, and value } 0 \text { if neither of the parents is self-employed } \\
\text { (Not self-employed = reference category) }\end{array}$ \\
\hline School calendar & $\begin{array}{l}\text { taking dummy variables, } 1 \text { if calendar is respected and } 0 \text { Otherwise } \\
\text { (not respected = reference category) }\end{array}$ \\
\hline Desire for independence & $\begin{array}{l}\text { taking dummy variables, } 1 \text { if had a desire for independence and } 0 \text { otherwise } \\
\text { (had no desire for independence = reference category) }\end{array}$ \\
\hline Whether parents live together with him & $\begin{array}{l}\text { taking dummy variables, } 1 \text { if parents live together with him And, } 0 \text { otherwise } \\
\text { (don't live together =reference category) }\end{array}$ \\
\hline Year of graduation & $\begin{array}{l}\text { taking dummy variable, } 1 \text { if } 2017 \text { and, } 0 \text { otherwise } \\
\text { ( } 2016 \text { and before, reference category) }\end{array}$ \\
\hline
\end{tabular}


Table 2. Summary statistics of the variables under consideration total observations $(n)=$ 2548.

\begin{tabular}{|c|c|c|c|c|c|}
\hline \multicolumn{2}{|c|}{ variables } & \multirow{2}{*}{$\begin{array}{c}\text { Mean } \\
24,680\end{array}$} & \multirow{2}{*}{$\begin{array}{c}\text { Std dev } \\
3495\end{array}$} & \multirow{2}{*}{$\begin{array}{c}\text { Min } \\
19\end{array}$} & \multirow{2}{*}{$\begin{array}{r}\max \\
48\end{array}$} \\
\hline Age & & & & & \\
\hline \multirow{2}{*}{ Gender } & Male & 0516 & 0500 & 0 & 1 \\
\hline & female & 0484 & 0500 & 0 & 1 \\
\hline \multirow{2}{*}{ Field of study } & Business mgt courses & 0.359 & 0.480 & 0 & 1 \\
\hline & Others courses & 0641 & 0.480 & 0 & 1 \\
\hline \multirow{2}{*}{ Tutor's education } & Educated & 0.442 & 0.497 & 0 & 1 \\
\hline & Not educated & 0.558 & 0.497 & 0 & 1 \\
\hline \multirow{2}{*}{ Self employed parents } & Self employed & 0.223 & 0.419 & 0 & 1 \\
\hline & Not self employed & 0.776 & 0.419 & 0 & 1 \\
\hline \multirow{2}{*}{ Parent's own business } & yes & 0144 & 0352 & 0 & 1 \\
\hline & no & 0856 & 0352 & 0 & 1 \\
\hline \multirow{2}{*}{ received Pocket money } & Yes & 0818 & 0386 & 0 & 1 \\
\hline & no & 0182 & 0386 & 0 & 1 \\
\hline \multirow{2}{*}{$\begin{array}{l}\text { Had a job while } \\
\text { at university }\end{array}$} & yes & 0092 & 0289 & 0 & 1 \\
\hline & no & 0908 & 0289 & 0 & 1 \\
\hline \multirow{3}{*}{$\begin{array}{l}\text { Parent's monthly } \\
\text { income }\end{array}$} & Below 100,000 & 0568 & 0495 & 0 & 1 \\
\hline & $100,000-199,000$ & 0274 & 0446 & 0 & 1 \\
\hline & More than 200,000 & 0159 & 0365 & 0 & 1 \\
\hline \multirow{2}{*}{ School calendar } & Yes & 0.654 & 0.476 & 0 & 1 \\
\hline & No & 0.346 & 0.476 & 0 & 1 \\
\hline \multirow{2}{*}{ Desire for independence } & Yes & 0.723 & 0.448 & 0 & 1 \\
\hline & No & 0.277 & 0.448 & 0 & 1 \\
\hline \multirow{2}{*}{$\begin{array}{l}\text { Whether parents live } \\
\text { together with him }\end{array}$} & yes & 0.774 & 0.418 & 0 & 1 \\
\hline & No & 0.226 & 0.418 & 0 & 1 \\
\hline Year of graduation & & 2014,861 & 0.562 & 2006 & 2019 \\
\hline
\end{tabular}

\section{Results}

To analyze and measure the entrepreneurial intentions of students, I have adopted the Multinomial Logit Model (MNL) for empirical analysis as proposed by Hosmer, Lemeshow and Sturdivant (2013) in their book titled "Applied Logistic Regression”. In order to apply multinomial logistic regression analysis in this study, the five-point likert scores were recorded and made into a categorical dependent variable.

Starkweather and Moske (2011) also suggest the application of multinomial logistic regression when the dependent variables are categorical since the estimation does not assume normality, linearity and homoscedasticity. They further 
imply that multinomial logistic regression assumes that the choices in the dependent variable are not related to each other.

Multinomial regression is taken to discuss the relationship between one nominal dependent variable and one or more independent variables. This technique offers a relaxed assumption of the linearity between the dependent and independent variables. Having more than two categories on a single dependent variable in the model, this technique is appropriate (Fox, 2000).

The mathematical functions are modelled as follows:

$$
\begin{aligned}
G_{1}(x) & =\ln \frac{\operatorname{Pr}(Y=1 / X)}{\operatorname{Pr}(Y=0 / X)}=\beta_{1} \cdot X_{i} \\
& =\beta_{10}+\beta_{11} x_{1}+\beta_{12} x_{2}+\cdots+\beta_{1 p} x_{p} \\
& =X^{\prime} \beta_{1}
\end{aligned}
$$

And

$$
\begin{aligned}
G_{2}(x) & =\ln \frac{\operatorname{Pr}(Y=2 / X)}{\operatorname{Pr}(Y=0 / X)}=\beta_{1} \cdot X_{i} \\
& =\beta_{20}+\beta_{21} x_{1}+\beta_{22} x_{2}+\cdots+\beta_{2 p} x_{p} \\
& =X^{\prime} \beta_{2}
\end{aligned}
$$

The conditional probabilities of each outcome category given the covariate vector are

$$
\begin{aligned}
& \operatorname{Pr}(Y=0 / X)=\frac{1}{1+\mathrm{e}^{g_{1}(X)}+\mathrm{e}^{g_{2}(X)}} \\
& \operatorname{Pr}(Y=1 / X)=\frac{\mathrm{e}^{g_{1}(X)}}{1+\mathrm{e}^{g_{1}(X)}+\mathrm{e}^{g_{2}(X)}} \\
& \operatorname{Pr}(Y=2 / X)=\frac{\mathrm{e}^{g_{2}(X)}}{1+\mathrm{e}^{g_{1}(X)}+\mathrm{e}^{g_{2}(X)}}
\end{aligned}
$$

The more general expression for the conditional probability in the three-category model is

$$
\operatorname{Pr}(Y=j / X)=\frac{\mathrm{e}^{g_{j}(X)}}{1+\sum_{k=0}^{2} \mathrm{e}^{g_{j}(X)}}
$$

In order to ascertain the model fitting information, the following hypothesis has also been developed as a first stage analysis to confirm the empirical results:

H0: there is no difference between the model without independent variables.

$\mathrm{H} 1$ : there is a difference between the model without independent variables.

The strength of the multinomial logistic regression relationship has been measured by considering the value of the pseudo-R-square. Chi square values and pseudo R2 values are reported in Table 3.

While testing the null hypothesis that there is no difference between the model without independent variables and the model with the independent variables. The chi-squared values have been utilized to test the statistical significance. As evident from Table 3 , the probability of the model chi-squared was 0.000 , less 
Table 3. Chi square values and pseudo R2 values.

\begin{tabular}{cc}
\hline Multinomial logistic regression & No of observations $=2548$ \\
LR chi2 $(28)=164,89$ & \\
Probability $>$ chi $2=0.0000$ & pseudo R $2=0.0306$ \\
Log likelihood $=-2607.82$ & . \\
\hline
\end{tabular}

than the significance level of 0.01 . Therefore, we reject the null hypothesis that there is no difference between the model without independent variables and the model with independent variables and accept the alternate hypothesis that there exists a relation between the independent variables and the dependent variables.

The pseudo- $\mathrm{R}$ square value from Table 3 shows that 3.06 percent of the variability is explained by this set of variables used in the model.

Estimation results from the multinomial logit model are presented in Table 4.

Table 4 highlights the estimate of the analysis adopted for the study as dependent variable was recoded into categorical variable. Two different estimates were generated in comparison to the base outcome. For this study, disagree was assigned as a base outcome or reference variable and estimates for the variable neutral and agree were generated in order to compare with the base outcome. However, as the variable neutral does not provide any significance, in comparison to the base outcome, only the estimates generated from the variable agree are presented in comparison with the base outcome.

Results from logistic regression analysis showed that gender, tutor education, Field of study, parents own a business, having a job while at university, Parent's monthly income, desire for independence, living with parents together, school calendar) were the key factors that influence students' entrepreneurial intention.

\subsection{Gender and Entrepreneurial Intention}

The estimation results from the gender perspective on entrepreneurial intention show that females are less likely to venture into entrepreneurship, the estimates show that in comparison to male, a female is 7.1 percent less likely to become an entrepreneur which is significant at a 1 percent level of significance.

The reasons for lower female interest in entrepreneurship may relate to a number of factors, such as personal background and experience and reduced perceptions of skill and self-efficacy. Gender may relate to such factors as "need for achievement" (McClelland, 1961), confidence or over-confidence (Busenitz and Barney, 1997) and propensity to take risk (Mustafa \& Abbas, 2021). Evidence from psychology implies that females have higher risk aversion tendencies than males (Arch, 1993; Byrnes et al., 1999).

\subsection{Effect of Tutor Education on Entrepreneurial Intention}

Likewise, tutor (father, mother or guardian depending on who was the household head) education level was another factor with a very strong contribution to predicting graduates' entrepreneurial intention. The results were statistically highly significant at a 10 percent level of significance. 
Table 4. Estimation results from the multinomial logit model total observations $(\mathrm{n})=$ 2548.

\begin{tabular}{|c|c|c|c|c|}
\hline \multirow[b]{2}{*}{ Variables } & \multicolumn{2}{|c|}{ neutral } & \multicolumn{2}{|c|}{ Agree } \\
\hline & coefficient & $\begin{array}{c}\text { Marginal } \\
\text { effect }\end{array}$ & coefficient & $\begin{array}{c}\text { Marginal } \\
\text { effect }\end{array}$ \\
\hline Age & $\begin{array}{l}0.262^{\star *} \\
(0.123)\end{array}$ & $\begin{array}{c}0.036 \\
(0.023)\end{array}$ & $\begin{array}{l}0.192^{\star} \\
(0.132)\end{array}$ & $\begin{array}{c}0.002 \\
(0.022)\end{array}$ \\
\hline female & $\begin{array}{c}-0.315^{\star * *} \\
(0.111)\end{array}$ & $\begin{array}{c}0.005 \\
(0.021)\end{array}$ & $\begin{array}{c}-0.551^{\star * *} \\
(0.119)\end{array}$ & $\begin{array}{c}-0.071^{\star * *} \\
(0.019)\end{array}$ \\
\hline Tutor's education & $\begin{array}{l}-0.059 \\
(0.135)\end{array}$ & $\begin{array}{l}-0.037 \\
(0.025)\end{array}$ & $\begin{array}{c}0.151 \\
(0.143)\end{array}$ & $\begin{array}{l}0.041^{\star} \\
(0.023)\end{array}$ \\
\hline Field of study & $\begin{array}{c}0.293^{\star * *} \\
(0.117)\end{array}$ & $\begin{array}{l}-0.014 \\
(0.021)\end{array}$ & $\begin{array}{c}0.576^{\star * *} \\
(0.123)\end{array}$ & $\begin{array}{c}0.079^{* * *} \\
(0.019)\end{array}$ \\
\hline $\begin{array}{l}\text { Self-employed } \\
\text { parents }\end{array}$ & $\begin{array}{c}0.032 \\
(0.154)\end{array}$ & $\begin{array}{c}0.038 \\
(0.028)\end{array}$ & $\begin{array}{l}-0203 \\
(0164)\end{array}$ & $\begin{array}{c}-0.048^{*} \\
(0.026)\end{array}$ \\
\hline $\begin{array}{l}\text { Parent's own } \\
\text { business }\end{array}$ & $\begin{array}{l}0.326^{*} \\
(0.175)\end{array}$ & $\begin{array}{l}-0.026 \\
(0.030)\end{array}$ & $\begin{array}{c}0.711^{\star * *} \\
(0.178)\end{array}$ & $\begin{array}{c}0.103^{\star * *} \\
(0.026)\end{array}$ \\
\hline $\begin{array}{c}\text { Received } \\
\text { pocket money }\end{array}$ & $\begin{array}{c}0.001^{*} \\
(0.137)\end{array}$ & $\begin{array}{c}0.004 \\
(0.026)\end{array}$ & $\begin{array}{l}-0.024 \\
(0.148)\end{array}$ & $\begin{array}{l}-0.005 \\
(0.024)\end{array}$ \\
\hline $\begin{array}{l}\text { Had a job while } \\
\text { at university }\end{array}$ & $\begin{array}{l}-0.323 \\
(0.178)\end{array}$ & $\begin{array}{c}0.006 \\
(0.037)\end{array}$ & $\begin{array}{c}0.570^{\star * *} \\
(0.201)\end{array}$ & $\begin{array}{c}-0.074^{\star *} \\
(0.036)\end{array}$ \\
\hline $\begin{array}{c}\text { Parent's } \\
\text { monthly income } \\
(100,000-199,999)\end{array}$ & $\begin{array}{c}0.022 \\
(0.138)\end{array}$ & $\begin{array}{c}0.006 \\
(0.037)\end{array}$ & $\begin{array}{l}-0.570 \\
(0.201)\end{array}$ & $\begin{array}{c}0.012 \\
(0.024)\end{array}$ \\
\hline $\begin{array}{l}\text { Parent's monthly } \\
\text { income (more than } \\
200,000)\end{array}$ & $\begin{array}{c}0.053 \\
(0.180)\end{array}$ & $\begin{array}{l}-0.005 \\
(0.026)\end{array}$ & $\begin{array}{l}0.073^{\star} \\
(0.148)\end{array}$ & $\begin{array}{l}0.058^{\star} \\
(0.030)\end{array}$ \\
\hline School calendar & $\begin{array}{l}0.182^{*} \\
(0.114)\end{array}$ & $\begin{array}{l}-0.030 \\
(0.022)\end{array}$ & $\begin{array}{c}0.503^{\star * *} \\
(0.125)\end{array}$ & $0.080^{* * *}$ \\
\hline $\begin{array}{c}\text { Desire for } \\
\text { independence }\end{array}$ & $\begin{array}{l}0.196^{\star} \\
(0.131)\end{array}$ & $\begin{array}{l}-0.011 \\
(0.026)\end{array}$ & $\begin{array}{c}0.394^{\star * *} \\
(0.145)\end{array}$ & $\begin{array}{l}0.055^{\star *} \\
(0.024)\end{array}$ \\
\hline $\begin{array}{l}\text { Whether parents } \\
\text { live together } \\
\text { with him }\end{array}$ & $\begin{array}{l}0.229^{\star} \\
(0.137)\end{array}$ & $\begin{array}{c}0.022 \\
(0.027)\end{array}$ & $\begin{array}{c}0.526^{\star * *} \\
(0.154)\end{array}$ & $\begin{array}{c}0.078^{\star * *} \\
(0.026)\end{array}$ \\
\hline Year of graduation & $\begin{array}{c}0.031 \\
(0.182)\end{array}$ & $\begin{array}{c}0.003 \\
(0.034)\end{array}$ & $\begin{array}{c}0.030 \\
(0.195)\end{array}$ & $\begin{array}{c}0.002 \\
(0.032)\end{array}$ \\
\hline Constant & $\begin{array}{c}0.212 \\
(0.237)\end{array}$ & & $\begin{array}{c}0.746 \\
(0.263)\end{array}$ & \\
\hline $\mathrm{R}$ squared & 0.031 & & 0.031 & \\
\hline Disagree & & & tcome & \\
\hline
\end{tabular}

Note: ${ }^{* \star},{ }^{* *}$ and ${ }^{\star}$ represent significant at $1 \%, 5 \%$ and $10 \%$ respectively. Source: Survey data 2019 . 
In other words, a graduate whose tutor is educated is 4.1 percent more likely to become entrepreneur.

These findings confirm the findings by Van Praag (2005) who observed that parental background characteristics such as education or job level of the father and sometimes mother influence the probability of starting up a firm but not entrepreneurial performance. People are more likely to become entrepreneurs if their father was also an entrepreneur and/or if their father had a higher qualified job or a higher level of education.

\subsection{Effect of Field of Study and Entrepreneurial Intention}

In terms of academic courses undertaken while at university, the estimates indicate that a graduate who has undertaken an entrepreneurial course is 7.9 percent more likely to take up entrepreneurship as a career option which is statistically significant at a 1 percent level of significance.

Entrepreneurship intention is very much associated with entrepreneurial knowledge which begins from within the family and this knowledge can stimulate the entrepreneurial intentions.

Similar findings were obtained by Siyanbola et al. (2009) who studied the determinants of entrepreneurial propensity of Nigerian undergraduates and found that entrepreneurial education, among other things influenced entrepreneurial propensity of Nigerian undergraduates. The authors further argue that entrepreneurship training and communication initiatives are key sources of positive entrepreneurial influence.

\subsection{Effect of Parents Own a Business on Entrepreneurial Intention}

A graduate whose parent owns a business is 10.3 percent more likely to become an entrepreneur and is statistically significant at a 1 percent level of significance.

Graduates recalled the influence of business enterprise on their lives as they were growing up. They understood the value their families placed on their business and were observers and participants over the years; involved in sharing conversations and discussions; learning values, commitment, personal responsibility, accountability, hard work and understanding along with other aspects of family life.

This finding is not surprising, as it is in line with the results provided by (Bosma et al., 2012; Carr \& Sequeira, 2007; Laspita et al., 2012; Oren, Caduri, \& Tziner, 2013), among others.

Graduates who had a job while studying at the university were 7.4 percent less likely to become entrepreneurs which are statistically significant at a 5 percent level of significance.

\subsection{Effect of Having a Job While at University on Entrepreneurial Intention}

With regard to the entrepreneurial intentions among those graduates who were 
already employed while pursuing their studies at the university, the estimates show that those graduates who had a job were less likely to become entrepreneurs in comparison to their counter parts who did not have a job while studying.

Graduates who had a job while studying at the university were 7.4 percent less likely to become entrepreneurs which is statistically significant at a 5 percent level of significance.

\subsection{Effect of Parents Monthly Income on Entrepreneurial Intention}

While measuring parent's monthly income and the corresponding impact on their children perception towards entrepreneurship, the estimates show that as the parent's monthly income increases over 200,000 a month, the probability of entrepreneurial intention exist. The estimates claim that a graduate whose parent's monthly income is more than 200,000 is 5.8 percent more likely to have entrepreneurial intention when compare to those graduates whose parent's earnings are less than 200,000 a month which is statistically significant at a 10 percent level of significance.

\subsection{Effect of Desire of Independence on Entrepreneurial Intention}

The relationship between desire for independence, and entrepreneurial intention was statistically significant at a 5 percent level of significance. This finding converges with the study of Douglas \& Fitzsimmons, 2005 who said that, generally, individuals who possess high need for independence will seek for careers with more freedom (Lee \& Wong, 2004). Wilson et al. (2004) resolved that teenager in Hispanic and African American who like entrepreneurship are motivated by motivational factor such as desire for independence. This implies that students with a strong desire for independence are likely to possess a higher level in entrepreneurial intentions.

\subsection{Effect of Graduate for Living with Parents Together on Entrepreneurial Intention}

Joint family pattern of living is a force to be reckoned with in providing a base in entrepreneurship the results from joint family encouraging to consider entrepreneurship as a career choice show that the likelihood of a graduate to endeavor into entrepreneurship increases by 7.8 percent if a graduate live together with parents. The estimates have been found statistically significant at a 1 percent level of significance.

\subsection{Effect of School Calendar on Entrepreneurial Intention}

Another important determinant of graduates' drive and determination is school calendar. School calendar generally refers to the turbulence occurred this last five year due to the strike in repetition. University staff launched an indefinite 
strike since on unpaid wages. The findings showed that school calendar significantly predicts graduates' drive and determination.

These strikes are used to pressure governments to pay wages and to change policies of universities infrastructural development and welfare of both Academic and non-Academic staff union of universities. Strikes are often part of a broader social movement taking the form of a campaign of civil resistance undertaken by unions during collective bargaining. Strike consists of workers refusing to attend word and picketing outside the workplace to prevent or dissuade people from working in their place or conducting business with their employer.

Irregularity of academic programs, examination malpractices and cultism amongst students, certificate racketeering, erosion of dignity and respect of higher education motivate and hinder the entrepreneurial intentions among university students in Congo Brazzaville. The estimates have been found statistically significant at a 1 percent level of significance.

Estimates from variables such as age, year of graduation, whether they received pocket money or not and household income level between 100,000 199,000 was not found statistically significant in this analysis.

\section{Conclusion}

The implementation of this study was to identify the motivational factors which can support Marien Ngouabi university student in Congo Brazzaville to become entrepreneurs.

The finding of this study is presented through descriptive analysis as well as through econometric model. Logistic regression model was adopted for the econometric analysis.

Results from logistic regression analysis showed that gender, tutor education, Field of study, parents owning a business, having a job while at university, Parent's monthly income, desire for independence, living with parents together, school calendar were the key factors that influence students' entrepreneurial intention.

There is a relationship between entrepreneurial education and entrepreneurial intentions.

Findings from the empirical analysis show that there exists some aspect of gender differences while considering entrepreneurship as a career choice. The study claims that female graduates are less likely to become entrepreneurs as compared to male graduates.

Concerning academic courses undertaken while at university, graduates who have pursued business management courses are more likely to opt entrepreneurship as a career as those graduates who have pursued other courses.

Irregularity of academic program, examination malpractices and cultism amongst students, certificate racketeering, and erosion of dignity motivate and hinder the entrepreneurial intentions among graduates students this situation 
confirm hypothesis. Congolese graduate students have high attitudes towards self-employment, actually this indicates that the respondent is more in favor of self-employment than organizational employment.

\section{Suggestions}

This research has significant consequences of implementing the educational system and political change for enhancement of entrepreneurship in order of quantity and quality for those who have ideas for business startups. The study suggests that the universities should focus their attention on attracting students towards entrepreneurial education as students who attended entrepreneurial courses/ trainings showed significantly higher entrepreneurial intentions. Therefore, universities are recommended to expand the number of entrepreneurship courses/ trainings as well as provide the opportunity to take entrepreneurial course/ training to the students from all the faculties/departments of this university. Universities should inculcate entrepreneurial intention among the students.

It is important to increase the opportunities of seminaries in order to facilitate interaction between experienced entrepreneurs and the students.

\section{Areas for Further Research}

Further studies should expand the study to the other universities in Congo.

\section{Conflicts of Interest}

The author declares no conflicts of interest regarding the publication of this paper.

\section{References}

Acheampong, G., \& Tweneboah-Koduah, E. Y. (2018). Does Past Failure Inhibit Future Entrepreneurial Intent? Evidence from Ghana. Journal of Small Business and Enterprise Development, 25, 849-863. https://doi.org/10.1108/JSBED-03-2017-0128

Adze et al. (2018). What Push Student to Have Entrepreneurship Intentions. Journal of Asia Industrial Training, 21, 154-160.

Ajzen, I. (1991). The Theory of Planned Behavior. Organizational Behavior and Human Decision Processes, 50, 179-211. https://doi.org/10.1016/0749-5978(91)90020-T

Alkhatib, K., Al-Aiad, A., Mustafa, M., \& Alzubi, S. (2020). Impact Factors Affecting Entrepreneurial Intention of Jordanian Private Universities Students: A Mediation Analysis of Perception toward Entrepreneurship. In Sustainable and Energy Efficient Computing Paradigms for Society (pp. 53-65). Springer. https://doi.org/10.1007/978-3-030-51070-1_3

Alla, A. A., \& Rajâa, O. (2019). Contribution to the Study of Social Entrepreneurial Intent among African University Students: Case of Seven Moroccan Universities. International Journal of Business and Social Science, 10, 8. https://doi.org/10.30845/ijbss.v10n8p8

Arch, E. C. (1993). Risk-Taking: A Motivational Basis for Sex Differences. Psychological Reports, 73, 3-11. https://doi.org/10.2466/pr0.1993.73.1.3

Bird, B. (1988). Implementing Entrepeneurial Ideas: The Case for Intention. Academy of 
Management Review, 13, 442-453. https://doi.org/10.5465/amr.1988.4306970

Bosma, N. S., Wennekers, S., \& Amorós, J. E. (2012). Global Entrepreneurship Monitor 2011 Extended Global Report: Entrepreneurs and Entrepreneurial Employees across the Globe. BabsonCollege, Santiago, Chile: Universidad del Desarollo, Universiti Tun AbdulRazak and Global Entrepreneurship Research Association.

Boyd, N. G., \& Vozikis, G. S. (1994). The Influence of Self-Efficacy on the Development of Entrepreneurial Intentions and Actions. Entrepreneurship Theory \& Practice, 1, 63-77. https://doi.org/10.1177/104225879401800404

Busenitz, L. W., \& Barney, J. B. (1997). Differences between Entrepreneurs and Managers in Large Organizations: Biases and Heuristics in Strategic Decision-Making. Journal of Business Venturing, 12, 9-30. https://doi.org/10.1016/S0883-9026(96)00003-1

Byrnes, J. P., Miller, D. C., \& Schafer, W. D. (1999). Gender Differences in Risk Taking: A Meta-Analysis. Psychological Bulletin, 125, 367-383.

https://doi.org/10.1037/0033-2909.125.3.367

Cantillon, R. (1755). Essai Sur La Nature Du Commerce en General. Gyles.

Carr, J., \& Sequeira, J. (2007). Prior Family Business Exposure as Intergenerational Influence and Entrepreneurial Intent: A Theory of Planned Behaviour Approach. Journal of Business Research, 60, 1090-1098. https://doi.org/10.1016/j.jbusres.2006.12.016

Dahlstedt, M., \& Fejes, A. (2019). Shaping Entrepreneurial Citizens: A Genealogy of Entrepreneurship Education in Sweden. Critical Studies in Education, 60, 462-476. https://doi.org/10.1080/17508487.2017.1303525

Davidsson, P. (1995). Determinants of Entrepreneurial Intentions. In the RENT IX Workshops (pp. 23-24). Piacenza.

Douglas, E. J., \& Fitzsimmons, J. R. (2005). Entrepreneurial Intentions towards Individual vs. Corporate Entrepreneurship. SEAANZ 2005 Conference, Armidale.

Elliott, C., Mavriplis, C., \& Anis, H. (2020). An Entrepreneurship Education and Peer Mentoring Program for Women in STEM: Mentors' Experiences and Perceptions of Entrepreneurial Self-Efficacy and Intent. International Entrepreneurship and Management Journal, 16, 43-67. https://doi.org/10.1007/s11365-019-00624-2

Fishbein, M., \& Ajzen, I. (1975). Belief, Attitude, Intention and Behavior: An Introduction to Theory and Research. Addison-Wesley.

Fox, J. (2000). Multiple and Generalized Nonparametric Regression. Sage. https://doi.org/10.4135/9781412985154

Hisrich, R. et al. (2005). Entrepreneurship Research and Practice: A Call to Action for Psychology. American Psychologist, 62, 575-589. https://doi.org/10.1037/0003-066X.62.6.575

Hosmer, D. W., Lemeshow, S., \& Sturdivant, R. X. (2013). Applied Logistic Regression. Wiley. https://doi.org/10.1002/9781118548387

Iakovleva, T., \& Kolvereid, L. (2009). An Integrated Model of Entrepreneurial Intentions. Inernational Journal of Business and Globalisation, 3, 66-80. https://doi.org/10.1504/IJBG.2009.021632

Iro-Idoro et al. (2017). Entrepreneurship Education and Self-Efficacy: Strategies for Reducing Unemployment Problem among Nigerian Graduates. IOSR Journal of Humanities and Social Science (IOSR-JHSS), 22, 34-39.

https://doi.org/10.9790/0837-22030498104

Ismail, M., Ibrahim, A. F., Yaacob, M. R., Ibrahim, A. H., Zakaria, M. N., Razak, R. C., Yusoff, M. N. K., Guan, T. T., \& Kamaruddin, A. N. (2018). Determine Entrepreneurial Characteristics Using Mobile Android Game Freezer. International Journal of Interac- 
tive Mobile Technologies, 12, 141-150. https://doi.org/10.3991/ijim.v12i1.7790

Krueger Jr., N. F., Reilly, M. D., \& Carsrud, A. L. (2000). Competing Models of Entrepreneurial Intentions. Journal of Business Venturing, 15, 411-432. https://doi.org/10.1016/S0883-9026(98)00033-0

Laspita, S., Breugst, N., Heblich, S., \& Patzelt, H. (2012). Intergenerational Transmission of Entrepreneurial Intentions. Journal of Business Venturing, 27, 414-435. https://doi.org/10.1016/j.jbusvent.2011.11.006

Lee, S. H., \& Wong, P. K. (2004). An Exploratory Study of Technopreneurial Intentions: A Career Anchor Perspective. Journal of Business Venturing, 19, 7-28. https://doi.org/10.1016/S0883-9026(02)00112-X

McClelland, D. (1961). The Achieving Society. Collier-Macmillan Free Press. https://doi.org/10.1037/14359-000

Morris, M. H. et al. (2005). The Entrepreneur's Business Model: Toward a Unified Perspective. Journal of Business Research, 58, 726-735. https://doi.org/10.1016/j.jbusres.2003.11.001

Mustafa, M., \& Abbas, A. (2021). Comparative Analysis of Green ICT Practices among Palestinian and Malaysian in SME Food Enterprises during COVID-19 Pandemic. PaIArch's Journal of Archaeology of Egypt/Egyptology, 18, 254-264.

Mustafa, M., Alzubi, S., \& Alshare, M. (2020). The Moderating Effect of Demographic Factors Acceptance Virtual Reality Learning in Developing Countries in the Middle East. In International Conference on Advances in Computing and Data Sciences (pp. 12-23). Springer. https://doi.org/10.1007/978-981-15-6634-9_2

Nabil, A. (2021). Toward a Comprehensive Model on Entrepreneurial Intentions of University Students. Open Journal of Business and Management, 9, 114-135. https://doi.org/10.4236/ojbm.2021.91007

Nathani, N., \& Dwivedi, G. (2019). Influence of Technology Entrepreneurship on Entrepreneurial Intentions: A Cross Country Analysis. In Proceedings of 10th International Conference on Digital. https://doi.org/10.2139/ssrn.3319889

Nowiński, W., Haddoud, M. Y., Lančarič, D., Egerová, D., \& Czeglédi, C. (2019). The Impact of Entrepreneurship Education, Entrepreneurial Self-Efficacy and Gender on Entrepreneurial Intentions of University Students in the Visegrad Countries. Studies in Higher Education, 44, 361-379. https://doi.org/10.1080/03075079.2017.1365359

Oren, L., Caduri, A., \& Tziner, A. (2013). Intergenerational Occupational Transmission: Do Offspring Walk in the Footsteps of Mom or Dad, or Both? Journal of Vocational Behavior, 83, 1-551. https://doi.org/10.1016/j.jvb.2013.08.003

Parker, S. C. (2009). Economics of Self-Employment and Entrepreneurship (p. 568). Cambridge University Press.

Phong, N. D., Thao, N. T. P., \& Nguyen, N. P. (2020). Entrepreneurial Intent of Business Students: Empirical Evidence from a Transitional Economy. Cogent Business \& Management, 7, Article ID: 1747962. https://doi.org/10.1080/23311975.2020.1747962

Pihie, L., \& Akmaliah, Z. (2009). Entrepreneurship as a Career Choice: An Analysis of Entrepreneurial Self-Efficacy and Intention of University Students. European Journal of Social Sciences, 9, 338-349.

Räty, H., Komulainen, K., Hytti, U., Kasanen, K., Siivonen, P., \& Kozlinska, I. (2019). University Students' Perceptions of Their Abilities Relate to Their Entrepreneurial Intent. Journal of Applied Research in Higher Education, 11, 897-909. https://doi.org/10.1108/JARHE-07-2018-0119

Schumpeter, J. A. (1934). The Theory of Economic Development. Harvard University. 
Shapero, A., \& Sokol, L. (1982). The Social Dimensions of Entrepreneurship. In Encyclopedia of Entrepreneurship (pp. 72-90). Prentice-Hall.

Siyanbola et al. (2009). Determinants of Entrepreneurial Propensity of Nigerian Undergraduates: An Empirical Assessment. International Journal of Business Environment, 5, 1-29. https://doi.org/10.1504/IJBE.2012.044925

Starkweather and Moske (2011). Multinomial Logistic Regression. University of North Texas. http://www.unt.edu/rss/class/Jon/Benchmarks/MLR_JDS_Aug2011.pdf

Sun, D. L., Chen, H. H., Wu, P. J., \& Yang, D. (2020). Entrepreneurship Education Promotes Individual Entrepreneurial Intention: Does Proactive Personality Work? Open Access Library Journal, 7, 1-15. https://doi.org/10.4236/oalib.1106835

Van Praag, C. M. (2005). Successful Entrepreneurship: Confronting Economic Theory with Empirical Practice. Edward Elgar. https://doi.org/10.4337/9781845426880

Wärneryd, K. E. (1988). The Psychology of Innovative Entrepreneurship. In W. F. van Raaij, G. M. van Veldhoven, \& K. E. Wärneryd (Eds.), Handbook of Economic Psychology (pp. 404-447). Kluwer. https://doi.org/10.1007/978-94-015-7791-5_11

Wilson, F., Marlino, D., \& Kickul, J. (2004). Our Entrepreneurial Future: Examining the Diverse Attitudes and Motivations of Teens across Gender and Ethnic Identity. Journal of Developmental Entrepreneurship, 9, 177-197. 